\title{
Anal Cancer Clinical TNM Finding v7
}

National Cancer Institute

\section{Source}

National Cancer Institute. Anal Cancer Clinical TNM Finding v7. NCI Thesaurus. Code C90027.

A clinical finding about one or more characteristics of anal cancer, following the rules of the TNM AJCC v7 classification system. (from AJCC 7th Ed.) 